\title{
Municipal Wastewater Irrigation Quality and its Impacts on Selected Soil Properties Around Harar City, Eastern Ethiopia
}

Tasisa Temesgen Tolossa ( $\nabla$ tasisatemesgen@gmail.com )

Haramaya University https://orcid.org/0000-0001-8937-636X

\section{Method Article}

Keywords: Municipal Wastewater, Irrigation water quality, Soil physico-chemical, Heavy metal

Posted Date: September 7th, 2021

DOI: https://doi.org/10.21203/rs.3.rs-877661/v1

License: (우 (i) This work is licensed under a Creative Commons Attribution 4.0 International License. Read Full License 


\section{Abstract}

In many arid and semiarid countries, wastewater irrigation is becoming a common practice in agriculture. Commitment of government and social intervention for more effective waste management are the major constraints. The study was conducted in eastern Ethiopia to identify the impacts of municipal wastewater soil physicochemical properties and irrigation water quality. Soil samples were collected from different farm fields to determine the physical and chemical properties of soil, and heavy metal accumulation at different irrigation farms and wastewater samples were also analyzed. Manusipal wastewater taken from different study sites was categorized into three groups: control (nonirrigated), municipal wastewater irrigated farmland and municipal wastewater irrigated farmland. The results showed that bulk density was negatively decreased and moisture contents and total porosity were significantly increased. The soil EC, cadmium, lead available phosphorus, $\mathrm{OM}$, and $\mathrm{CEC}$ levels significantly increased with increasing wastewater application. The concentrations of $\mathrm{Zn}, \mathrm{Cu}, \mathrm{Cd}, \mathrm{Pb}$ and $\mathrm{Cr}$ are highwere higher in irrigated effluent than in nonirrigated effluent. Untreated and treated MWW were tested for heavy metal presence and accumulation. The soil OM increased as the content in the soil also increased as the number of irrigations increased. The most effective way to eliminate the impact of this municipal wastewater on the soil and water is to develop and implement an effective wastewater management plan. Limited studies have been done, and they should be encouraged to address municipal wastewater impacts on plants and farmers. The government should be focused on awareness of creation and management systems.

\section{Background}

In the increase of urban Irrigation agriculture, scarcity of water availability is major problem, and use of treated waste water for Irrigation Agriculture is becoming common practice [1\&2]. As human interests on natural resources increased, problem of natural resources like water availability is unquestinable [3 \& 4]. Due to high water scarcity problem wastewater used for domestic and agricultural practice without any properly management and quality standard use, but this make human health problem and yield failed [ 5]. Water insufficiency and wastewater generation is the major nervousness that impacts livelihood.

In Ethiopia, due to poor government policy on urban wastewater management, towns and cities in the country are becoming sources of solid and liquid waste. There are some activities of waste treatment use for agriculture, but there are very few, especially communities that are involved in wastewater treatment and used for irrigation and fertilizers. Nonetheless, limited studies have been done thus far on the impact of manusipal waste in particular on health and agricultural productivity. Some researchers have assessed the contents of wastewater generated from this city. However, the effect of municipal wastewater on soil properties and irrigation water quality has not been well investigated.

Therefore, the objectives of this study were to characterize municipal wastewater with selected chemical and physical properties, analyze its irrigation water quality and determine the impacts of wastewater irrigation on selected soil physical and chemical properties.

\section{Materials And Methods}




\subsection{Description of the Study Area}

The study was conducted in Harar City, which is known as African Mecca and was founded in 1007 Harari National Regional State, which is located in the eastern part of Ethiopia (Fig. 1). The Population of the cities is more than 215,000 . The city of Harar is the capital of Harari Regional State and capital city of eastern Hararghe zone of oromia region which is located in the East at a distance of $525 \mathrm{~km}$ from Addis Ababa. The site is located at latitude $9^{\circ} 24^{\prime} 57^{\prime \prime} \mathrm{N}$, longitude $42^{\circ} 2^{\prime} 23^{\prime \prime} \mathrm{E}$ and altitude 2023 meters above sea level. The site is representative of a subhumid mid-altitude agro-climatic zone. The rainfall distribution is bimodal, the short rainy season is from March to May, and the long rainy season is from June to October. The area receives a mean annual precipitation of $760 \mathrm{~mm}$. The mean annual maximum and minimum temperatures are $23.40^{\circ} \mathrm{C}$ and $8.25^{\circ} \mathrm{C}$, respectively.

In this city, manusipal wastewater originated from different sources like, such as from Harar Brewey Factory, officies, health centers, universities and collegies, schools, and marketies. which are produces high organic loading effluent. Farmers in downstream areas have been using this wastewater for many years. Due to developing countries, these ecosystems are often discharged into natural ecosystems without previous treatment.

\subsection{Sample Preparation and Laboratory Analysis of Wastewaters}

\subsubsection{Soil sampling, heavy metal accumulation in soil and analysis}

Soil samples were collected from the down farm field of the city of different farm field locations to determine the physical and chemical properties of the soil. Soil samples were mixed thoroughly, dried at room temperature, ground and sieved through a $2 \mathrm{~mm}$ screen for physical analysis, whereas for $\mathrm{OC}$ and total nitrogen determination, soil samples were passed through a $0.5 \mathrm{~mm}$ sieve.

Heavy metal accumulation soil was selected randomly from wastewater for analysis of major heavy metals ( $\mathrm{Zn}, \mathrm{Mn}, \mathrm{Fe}, \mathrm{Cu}, \mathrm{Cr}, \mathrm{As}, \mathrm{Ni}, \mathrm{Cd}$ ) using an atomic absorption instrument following [6]. For soil sample

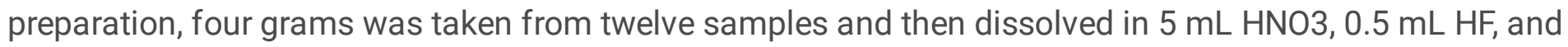
$0.5 \mathrm{~mL} \mathrm{HCl}$ in a Teflon vessel. Samples were dissolved in $6 \mathrm{~mL} 69 \% \mathrm{HNO}$ and $3 \mathrm{~mL} \mathrm{HCl}$ in a Teflon vessel in a microwave digestion system. The digested samples were then transferred into a Teflon beaker, and the volume was brought to $50 \mathrm{~mL}$ with deionized water. The digested solution was filtered by using a $0.45 \mu \mathrm{m}$ syringe filter and stored in $50 \mathrm{~mL}$ polypropylene tubes for analysis.

Analysis of the particle size distribution was performed by hydrometer method (differential settling within a water column) according to [7]. Organic carbon content was determined using [8] method. Soil texture was determined by the Bouyoucos hydrometer method [9]. The bulk density (BD) of the soil after crop harvest 
was measured from the undisturbed soil samples collected from each plot using a core sampler and determined according to the procedure described [10].

\subsubsection{Water Samples Analysis}

The collected wastewater samples were taken before and after wastewater treatment for the analysis of $\mathrm{pH}$, $\mathrm{EC}$, dissolved cation ( $\mathrm{Ca}, \mathrm{Mg}, \mathrm{Na}$ and $\mathrm{K})$, alkalinity $\left(\mathrm{HCO}_{3}\right.$ - and $\left.\mathrm{CO} 32-\right), \mathrm{Cl}^{-}, \mathrm{SO}_{4}{ }^{2-}, \mathrm{NO}_{3}$ - and boron (B) contents in the laboratory. The collected water samples were analyzed for TSS, $\mathrm{pH}, \mathrm{EC}, \mathrm{TDS}, \mathrm{Na}, \mathrm{Ca}, \mathrm{Mg}, \mathrm{Cl}$, SO-4, $\mathrm{NO}_{3}, \mathrm{NO}_{2}, \mathrm{~B}, \mathrm{CO}_{3}$ and $\mathrm{HCO}_{3}$. All these elements were determined according to international standards of laboratory analysis for the quality of irrigation water, such as hardness, nitrate, phosphorus content, and SAR.

The residual sodium carbonate (RSC) equation was used to determine the concentrations of $\mathrm{HCO}-, \mathrm{CO} 32-$, $\mathrm{Ca} 2+$ and $\mathrm{Mg} 2+$ ions as follows:

$\mathrm{RSC}=(\mathrm{HCO} 3-+\mathrm{CO} 2)-(\mathrm{Ca} 2++\mathrm{Mg} 2+)$

where concentrations are expressed in meq/I [11], and the SAR was calculated as:

$$
S A R=\frac{\left(\mathrm{Na}^{+}\right)}{\left(\mathrm{Ca}^{2+}+\mathrm{Mg}^{2+}\right)^{0.5}}
$$

where $\mathrm{Na}$ is the concentration of $\mathrm{Na}$ in the irrigation water expressed in $\mathrm{meq} / \mathrm{l}$.

\subsection{Data Analysis}

Statistical data analysis was performed to identify the impacts of wastewater irrigation on soil properties using $R$ software version 3.6.3 and for water quality for irrigation, and a t-test at $P \leq 0.05$ was used to compare significant differences between initial and final irrigation.

\section{Results And Discussion}

\subsection{Physical and Chemical Characteristics of Municipal Wastewater}

According to the results of municipal wastewater analysis value of $\mathrm{pH}$ at initial and final irrigation points were 8.14 and 8.26 (Table 1). The total dissolved solid (TDS) municipal wastewater varied in the range 762.54 to $945.32 \mathrm{mg} \mathrm{L}^{-1}$ from final to initial point. The BOD and COD values in the study sites were varied from $167.0 \mathrm{mg} / \mathrm{l}$ to $207.3 \mathrm{mg} / \mathrm{l}$ and $246.43 \mathrm{mg} / \mathrm{l}$ to $286 \mathrm{mg} / \mathrm{l}$ respectively (Table 1 ), Concentration of sodium in municipal wastewater varied in the range of 33.3 to $44.5 \mathrm{mg} \mathrm{L}^{-1}$ at the final to initial discharge points (Table 1). The initial and final point concentration of ammonium-nitrogen and nitrate-nitrogen were 7.56 to $14.25 \mathrm{mg} / \mathrm{l}$ and 9.43 to $11.60 \mathrm{mg} / \mathrm{l}$ respectively (Table 1 ). 
Table 1

Characteristics of municipal wastewater quality

\begin{tabular}{|c|c|c|c|c|c|}
\hline \multicolumn{6}{|c|}{ Descriptive Statistics } \\
\hline Parameters & Initial point & Final point & Mean & $\mathrm{SD}(+)$ & FAO/WHO Perm. Limits \\
\hline $\mathrm{pH}$ & 8.26 & 8.14 & 8.2 & 0.085 & $6.5-8.4$ \\
\hline $\mathrm{EC}, \mathrm{dS} / \mathrm{m}$ & 2.34 & 2.32 & 2.33 & 0.014 & $0.7-3.0$ \\
\hline TDS, mg/l & 945.32 & 762.54 & 853.93 & 129.24 & $450-2000$ \\
\hline $\mathrm{TSS}, \mathrm{mg} / \mathrm{l}$ & 67.98 & 49.65 & 58.82 & 12.96 & 50 \\
\hline $\mathrm{DO}, \mathrm{mg} / \mathrm{l}$ & 0.0045 & 0.0003 & 0.002 & 0.002 & $5-6$ \\
\hline BOD, mg/l & 207.3 & 167.0 & 185.15 & 28.49 & 60 \\
\hline COD, mg/l & 288 & 246.43 & 266.22 & 27.98 & 200 \\
\hline $\mathrm{Na}^{+}, \mathrm{mg} / \mathrm{l}$ & 44.5 & 33.3 & 38.9 & 7.92 & 200 \\
\hline $\mathrm{Ca}^{2+}, \mathrm{mg} / \mathrm{l}$ & 74.8 & 64.2 & 69.5 & 7.49 & 400 \\
\hline $\mathrm{Mg}^{2+}, \mathrm{mg} / \mathrm{l}$ & 54.3 & 49.6 & 51.95 & 3.32 & 60 \\
\hline $\mathrm{K}^{+}, \mathrm{mg} / \mathrm{l}$ & 66.33 & 51.44 & 58.84 & 10.46 & $<10$ \\
\hline $\mathrm{HCO}_{3}{ }^{-}, \mathrm{mg} / \mathrm{l}$ & 40.5 & 35.3 & 37.9 & 3.676 & $1.5-8.5$ \\
\hline $\mathrm{CO}_{3}{ }^{2-}, \mathrm{mg} / \mathrm{l}$ & 24.5 & 19.4 & 21.95 & 3.606 & $<10$ \\
\hline $\mathrm{NH}_{4-} \mathrm{N}, \mathrm{mg} / \mathrm{l}$ & 14.25 & 7.56 & 10.91 & 4.73 & - \\
\hline $\mathrm{NO}_{3}-\mathrm{N}, \mathrm{mg} / \mathrm{l}$ & 11.60 & 9.43 & 10.52 & 1.53 & $5-30$ \\
\hline $\mathrm{TN}, \mathrm{mg} / \mathrm{l}$ & 29.6 & 24.78 & 27.19 & 3.408 & $5-30$ \\
\hline $\mathrm{P}, \mathrm{mg} / \mathrm{l}$ & 9.43 & 8.64 & 9.04 & 0.56 & $<10$ \\
\hline SAR & 4.988 & 4.414 & 4.701 & 0.794 & $3-9$ \\
\hline ESP \% & 6.538 & 5.538 & 5.763 & 1.096 & - \\
\hline
\end{tabular}

The mean ion concentrations in wastewater at both sample collection sites were compared by t-tests at a confidence level of $95 \%$. Among the two sites, wastewater samples taken from the initial points and final 
points showed significant differences ( $\mathrm{s}$ 0.05), and this variation might be due to natural processes of water.

\subsection{Impacts of Municipal Wastewater on Soil Physical Properties}

At wastewater irrigation sites, there were no significant differences in soil moisture under $\mathrm{MWWI}<10$ and $\mathrm{MWWI}>10$. Both nonirrigated and irrigated farmland showed significant differences at the $p<0.05$ level in the soil moisture results (Table 2). This variation might be due to the higher contents of organic matter generated from municipal wastewater. The presented result was in agreement with [12, 13, 14 and 15] variation in bulk density, total porosity and soil moisture contents between the irrigated and control sites, which might be due to the addition of organic matter in irrigated farmland (Table 2).

Clay contents were highly and significantly different between the nonirrigated and irrigated farmland. The highest clay content (26\%) was recorded for nonirrigated farmland, whereas the lowest value (23\%) was recorded for wastewater-irrigated farmland (Table 2). On the other hand, the lowest clay content was recorded at the farmland irrigated for more than ten years. The dominant soil particle in the study sites was sand followed by clay and silt. Silt content was the least at all sites.

Table 2

Selected physical properties of the soil at the study sites

\begin{tabular}{|c|c|c|c|c|c|c|}
\hline \multirow[t]{2}{*}{ Descriptive Statics } & \multicolumn{3}{|c|}{ PSD \% } & \multirow[t]{2}{*}{$B D\left(\mathrm{~g} / \mathrm{cm}^{3}\right)$} & \multirow[t]{2}{*}{ TP $\%$} & \multirow[t]{2}{*}{ Moisture \% } \\
\hline & Sand & Silt & Clay & & & \\
\hline Control & 56 & 18 & $26^{a}$ & $1.56^{\mathrm{a}}$ & $41.1^{\mathrm{C}}$ & $10.86^{b}$ \\
\hline$M W W I<10$ & 61 & 15 & $24^{b}$ & $1.28^{\mathrm{b}}$ & $51.7^{\mathrm{b}}$ & $24.98^{a}$ \\
\hline$M W W I<10$ & 58 & 19 & $23^{c}$ & $1.15^{\mathrm{b}}$ & $56.6^{a}$ & $26.2^{\mathrm{a}}$ \\
\hline Mean & 58.33 & 17.3 & 24.33 & 1.33 & 46.4 & 20.68 \\
\hline $\operatorname{SD}( \pm)$ & 2.52 & 2.08 & 1.53 & 0.21 & 5.3 & 8.53 \\
\hline SL & NS & NS & 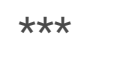 & $\star \star \star$ & $\star \star \star *$ & * \\
\hline \multicolumn{7}{|c|}{$\begin{array}{l}\text { MWWI }>10=\text { municipal wastewater irrigated for more than ten years, MWWI }<10=\text { brewery, municipal } \\
\text { wastewater irrigated for ten years, PSD = particle size distribution, } \mathrm{SL}=\text { significance level } \mathrm{NS}=\text { not } \\
\text { significant; }{ }^{*}=\text { significance at } p<0.05 ; * *=\text { significance at } p<0.01 ; * * *=\text { significance at the } p<0.001 \text { level }\end{array}$} \\
\hline
\end{tabular}

\subsection{Impacts of Municipal Wastewater on Soil Chemical Properties}


The results in Table 3 indicated that all soil chemical properties were slightly affected by the wastewater. At the study sites, the soil reaction was slightly alkaline in municipal wastewater-irrigated farmland. A higher $\mathrm{pH}$ value (7.74) was recorded with nonirrigated (control) farmland, and the lowest $\mathrm{pH}$ value (7.34) was recorded with irrigated farmland with municipal wastewater for less than ten years (Table 3 ). The variation in soil $\mathrm{pH}$ might be due to the presence of a high content of relatively ammonium in the wastewater (Table 1), resulting in its accumulation in the soil. This suggestion was supported by the finding of [16] that soil pH decreased with wastewater irrigation due to the oxidation of organic compounds and nitrification of ammonium. Nitrification of this ammonium would serve as a source of hydrogen ions, which may lead to a decrease in the soil pH [13].

The total soluble salt content expressed as electrical conductivity (EC) is an important indicator of soil health. It affects crop yields, plant nutrient availability, and the activity of soil microorganisms, which influence key soil processes [17]. The electrical conductivity of the soils was significantly influenced by the wastewater. The highest electrical conductivity $(0.328 \mathrm{dS} / \mathrm{m})$ was recorded for municipal wastewater for more than ten years (MWWI > 10) of irrigation, whereas the lowest value of EC was recorded for the nonirrigated site $(0.062 \mathrm{dS} / \mathrm{m})$ (Table 3$)$. At nonirrigated and irrigated farmland, the differences in soil electrical conductivity were significant $(P<0.001)$.

Wastewater irrigated farmland; soil electrical conductivity increased with increasing years of wastewater application. Additionally, the soil EC significantly increased at $\mathrm{MWWI}<10$ than at the MWWI $>10$ sites. The increase in EC (electrical conductivity) of the soil due to irrigation with wastewater is mainly attributed to the high level of TDS (total dissolved solids) of the wastewater that would accumulate in the soil with continuous wastewater application. This result is in harmony [18 \& 19]. 
Table 3

$\mathrm{pH}, \mathrm{EC}(\mathrm{dS} / \mathrm{m})$, and heavy metal $(\mathrm{mg} / \mathrm{kg})$ concentration of soil at different irrigation sites

Descriptive statistics

\begin{tabular}{|c|c|c|c|c|c|c|c|}
\hline & $\mathrm{pH}$ & $\mathrm{EC}$ & $\mathrm{Cu}$ & $\mathrm{Zn}$ & $\mathrm{Cd}$ & $\mathrm{Pb}$ & $\mathrm{Cr}$ \\
\hline Control & 7.74 & $0.062^{c}$ & 5.6 & 6.85 & $1.67^{\mathrm{c}}$ & $0.29^{b}$ & 0.54 \\
\hline$M W W I<10$ & 7.34 & $0.230^{\mathrm{b}}$ & 3.2 & 5.06 & $2.5^{\mathrm{b}}$ & $0.57^{\mathrm{a}}$ & 0.36 \\
\hline $\mathrm{MWWI}>10$ & 7.68 & $0.328^{a}$ & 4.53 & 8.43 & $3.33^{\mathrm{a}}$ & $0.57^{\mathrm{a}}$ & 0.54 \\
\hline $\mathrm{SD}( \pm)$ & 0.22 & 0.13 & 1.20 & 1.67 & 0.83 & 0.16 & 0.10 \\
\hline SL & NS & $\star \star \star *$ & NS & NS & 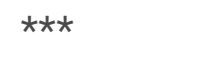 & * & NS \\
\hline FAO Perm. Limits & 6.5 & $<10$ & $1-12$ & $12-60$ & $0.02-0.5$ & $0.3-10$ & $0.002-0.2$ \\
\hline
\end{tabular}

\subsection{Total heavy metals}

The concentrations of $\mathrm{Zn}, \mathrm{Cu}, \mathrm{Cd}, \mathrm{Pb}$ and $\mathrm{Cr}$ at $\mathrm{MWWI}>10$ (municipal wastewater irrigated land for more than ten years) were $8.43,4.53,3.33,0.57$ and $0.54 \mathrm{mg} / \mathrm{kg}$, respectively (Fig. 2). However, at the nonirrigated site, the recorded results were $6.85,5.6,1.67,0.29$ and $0.54 \mathrm{mg} / \mathrm{kg}$ for $\mathrm{Zn}, \mathrm{Cu}, \mathrm{Cd}, \mathrm{Pb}$ and $\mathrm{Cr}$, respectively. The concentrations of $\mathrm{Cd}$ and $\mathrm{Pb}$ were significantly higher at irrigated sites than in nonirrigated areas. This might be due to the release of these elements by the fermentation process and their entry into the soil with irrigation water. According to [20 \& 21]. A large volume of waste water generation that is concentrated in metals is high in city, but use of treated waste water irrigation is low in developing countries.

\subsection{Organic matter (OM) and soil organic carbon (SOC)}

According to [22], organic matter is widely regarded as a vital component of soil fertility because of its role in physical, chemical and biological processes to supply plants with nutrients and to help soil maintain moisture. At wastewater irrigation sites, the organic matter content (OM) was positively and significantly influenced by wastewater. The highest organic matter (OM) content (2.69\%) was observed for the soil irrigated for more than ten years, whereas the lowest value of OM was recorded for the nonirrigated sites (Table 4). This might be due to the release of organic compounds by the brewing process and their entry into the soil with irrigation water. The present study was consistent with the finding [23], who reported that the soil organic matter content (OM) increased with wastewater irrigation application and depended on the period of application. According to [24], the organic matter content in the soil also increased as the number of irrigations increased, showing a benefit to the soil. The organic carbon contents of the soil were not 
significantly influenced by wastewater irrigation (Table 4). Soil organic carbon (SOC) is the most important indicator of soil quality and plays a major role in nutrient cycling [25].

Table 4

SOM (\%), SOC (\%), AVP (mg/kg) and TN (\%) concentrations at different sites.

\begin{tabular}{|c|c|c|c|c|}
\hline \multirow[t]{2}{*}{ Descriptive Statistics } & \multicolumn{3}{|c|}{ Parameters } & \multirow[b]{2}{*}{$\mathrm{TN}$} \\
\hline & SOM & $\mathrm{SOC}$ & AVP & \\
\hline Control & $1.35^{\mathrm{c}}$ & 0.999 & $9.71^{\mathrm{C}}$ & 0.19 \\
\hline$M W W I<10$ & $1.72^{\mathrm{b}}$ & 0.781 & $11.27^{b}$ & 0.20 \\
\hline MWWI > 10 & $2.69^{a}$ & 1.562 & $13.10^{\mathrm{a}}$ & 0.21 \\
\hline $\mathrm{SD}( \pm)$ & 0.60 & 0.40 & 1.69 & 0.005 \\
\hline SL & $\star *$ & NS & $\star \star \star *$ & NS \\
\hline
\end{tabular}

\subsection{Concentration of different MWWI Chemicals}

The soil AVP was significantly different $(p<0.001)$ in nonirrigated (control), municipal wastewater irrigation farmland for less than ten years $(\mathrm{MWWI}<10)$ and municipal wastewater irrigated farmland for more than ten years $(\mathrm{MWWI}>10)$.

The CEC was significantly different along the nonirrigated and irrigated farmland, as shown in Fig. 3. The highest CEC value was recorded in municipal wastewater-irrigated farmland for more than ten years, and the lowest value was observed in nonirrigated land. CEC was significantly higher in MWWI > 10 than in $\mathrm{MWWI}<$ 10 and nonirrigated (control) plants.

\subsection{Pearson's Correlation between Chemical Properties of Wastewater and}

\section{Wastewater Irrigated Soils}

The relationships between different chemical properties and ion concentrations of wastewater and wastewater irrigated soils were analyzed by Pearson's correlation coefficient. A high correlation coefficient 
(near +1 or -1 ) means a good relation between two variables, and zero means no relationship between them at a significance level of $0.05 \% . r>0.7$ indicates a strong correlation, whereas the $r$ value is between 0.5 and 0.7 , and it shows a moderate correlation between the two parameters.

Table 5. Pearson's correlation between chemical properties of wastewater and soils of different sites

\begin{tabular}{|c|c|c|c|c|c|c|c|c|c|c|}
\hline & $\mathrm{PH}$ & EC & $\mathrm{Ca}$ & $\mathrm{Mg}$ & $\mathrm{Na}$ & K & $\mathrm{TN}$ & AVP & SAR & ESP \\
\hline $\mathrm{PH}$ & 1 & & & & & & & & & \\
\hline EC & $0.994^{*}$ & 1 & & & & & & & & \\
\hline $\mathrm{Ca}$ & 0.963 & 0.927 & 1 & & & & & & & \\
\hline $\mathrm{Mg}$ & $0.999^{\star \star}$ & $0.997^{*}$ & 0.952 & 1 & & & & & & \\
\hline $\mathrm{Na}$ & 0.930 & 0.965 & 0.795 & 0.943 & 1 & & & & & \\
\hline K & $0.995^{\star}$ & 0.977 & 0.985 & $0.990^{\star}$ & 0.887 & 1 & & & & \\
\hline TN & $0.999^{\star \star}$ & 0.989 & 0.971 & $0.997^{\star}$ & 0.917 & 0.998 & 1 & & & \\
\hline AVP & -0.914 & -0.954 & -0.771 & -0.929 & $-0.999^{\star \star}$ & -0.868 & -0.900 & 1 & & \\
\hline SAR & $0.999^{\star *}$ & $0.994^{*}$ & 0.961 & $0.999^{\star \star}$ & 0.931 & $0.994^{*}$ & $0.999^{\star \star}$ & -0.916 & 1 & \\
\hline ESP & $0.999^{\star *}$ & 0.988 & 0.974 & $0.996^{\star}$ & 0.912 & $0.998^{\star \star}$ & $0.999^{\star \star}$ & -0.895 & $0.999^{* *}$ & 1 \\
\hline \multicolumn{11}{|c|}{$\begin{array}{l}\mathrm{EC}=\text { electrical conductivity; } \mathrm{TN}=\text { total nitrogen; } \mathrm{AVP}=\text { available phosphorus; } \mathrm{SAR}=\text { sodium adsorption } \\
\text { ratio and } \mathrm{ESP}=\text { exchangeable sodium percentage. }\end{array}$} \\
\hline \multicolumn{11}{|c|}{ ** Correlation is significant at 0.001 and * correlation is significant at 0.05} \\
\hline \multicolumn{11}{|c|}{$\begin{array}{l}\text { The results in Table } 5 \text { indicated that there was a significant and positive correlation between } \mathrm{pH}, \mathrm{Mg}, \mathrm{TN} \text {, } \\
\text { SAR and ESP }(\mathrm{P} \leq 0.001) \text { and that these parameters were significantly negatively correlated with } \\
\text { available phosphorus and significantly correlated with } \mathrm{pH}, \mathrm{EC} \text { and } \mathrm{K}^{+}(\mathrm{p} \leq 0.05) \text {. }\end{array}$} \\
\hline
\end{tabular}

\section{Conclusions And Recommendation}

Municipal wastewater is dependent on original sources of composition, and in this line, high concentrations of MWW can affect soul properties and change the composition of elemet in soil. The soil physicochemical analysis showed that BD significantly decreased wastewater irrigation by $17.94 \%$ and $26.23 \%$ for less than ten years, which is taken as the benchmark and wastewater irrigation for more than ten years, respectively, in irrigated farmland compared with nonirrigated farmland. Concentrations of $\mathrm{Zn}, \mathrm{Cu}, \mathrm{Cd}, \mathrm{Pb}$ and $\mathrm{Cr}$ were 
higher at the waste irrigation site than at the nonirrigated site. The most effective way to reduce/eliminate the impact of municipal wastewater on the soil is to develop and implement an effective wastewater management plan. Further investigations should be encouraged to address municipal wastewater impacts on plants and farmers. In general, the city municipality office and government should create a wastewater management system, establish acceptable levels or criteria related to chemicals, rule and regulation of wastewater treatment systems and recycle wastewater for sustainable use of resources and environmental protection.

\section{Declarations}

\section{Acknowledgments}

The authors I would like to express my deepest gratitude to Haramaya University Laboratory and Harari Regional state for facilitating my field and laboratory work.

\section{Compliance with ethical standards}

Conflict of interest The authors declare that there are no conflic-ts of interest associated with this study. The authors I would like to express my deepest gratitude Haramaya University Laboratory and Harari Region state for facilitating my field and laboratory work

\section{Author information}

Tasisa Temesgen is Lecturer, Researcher and Reviewer at Natural Resources Management program, Haramaya University. He is specialized in Irrigation Agronomy from Haramaya University, Ethiopia. His research interest is on Irrigation management, Soil and Water conservation, Irrigation Urban Agriculture. Tasisa has published several internationally peer reviewed papers.

\section{Authour Contribution}

Tasisa Temesgen contributed to the supervisor, proposal writing, experiment design, laboratory work, fieldwork, data collection, data analysis and interpretation using (R software version 3.6.3) and writing the manuscript.

\section{Funding}

This research did not receive any specific grant from funding agencies in the public, commercial, or not-forprofit sectors.

\section{Availability of data and materials}

Not applicable.

\section{Declarations Ethics approval and consent to participate}

Not applicable. 


\section{Consent for publication}

Not applicable.

\section{Competing interests}

The author declared that there is no conflict of interest.

\section{References}

[1] Ibrahim M. Makhadmeh, Seba F. Gharaiebeh and Ammar A. Albalasmeh. (2021). Impact of Irrigation with Treated Domestic Wastewater on Squash (Cucurbita pepo L.) Fruit and Seed under Semi Arid Conditions. Horticulturae 2021, 7, 226. https://doi.org/10.3390/horticulturae7080226

[2] Awoke Guadie, Asamin Yesigat, Shetie Gatew, Abebe Worku, Wenzong Liu, Mengist Minale, Aijie Wang. (2021). Effluent quality and reuse potential of urban wastewater treated with aerobic-anoxic system: A practical illustration for environmental contamination and human health risk assessment, Journal of Water Process Engineering, Volume 40, https://doi.org/10.1016/j.jwpe.2020.101891.

[3] Rasheed, F.; Zafar, Z.; Waseem, Z.A.; Rafay, M.; Abdullah, M.; Salam, M.M.A.; Mohsin, M.; Khan, W.R. (2020). Phytoaccumulation of $\mathrm{Zn}, \mathrm{Pb}$, and $\mathrm{Cd}$ in Conocarpus lancifolius irrigated with wastewater: Does physiological response influence heavy metal uptake? Int. J. Phytoremediat. 22, 287-294. [CrossRef]

[4] Quist-Jensen, C.A.; Macedonio, F.; Drioli, E. (2015). Membrane technology for water production in agriculture: Desalination and wastewater reuse. Desalination 2015, 364, 17-32. [CrossRef]

[5] Farhadkhani, M.; Nikaeen, M.; Yadegarfar, G.; Hatamzadeh, M.; Pourmohammadbagher, H.; Sahbaei, Z.; Rahmani, H.R. (2018). Effects of irrigation with secondary treated wastewater on physicochemical and microbial properties of soil and produce safety in a semiarid area. Water Res. 144, 356-364. [CrossRef]

[6] Abbruzzini, T.F.; Silva, C.A.; de Andrade, D.A.; de Oliveira Carneiro, W.J. (2014). Influence of digestion methods on the recovery of Iron, Zinc, Nickel, Chromium, Cadmium and Lead contents in 11 organic residues. Rev. Bras. Ciência Solo 2014, 38, 166-176. [CrossRef

[7] FAO (Food and Agricultural Organization), 2008. Soil Bulletin 55, Guidelines: Land Evaluation for Irrigated Agriculture. Agriculture Organization of the United Nation. Roma, Italy.

[8] Walkley A and Black A. (1934). An examination of degtjareff method for determining soil organic matter and a proposed modification of the chromic acid titration method, Soil Science, (37): 29-37,View at Google Scholar.

[9] Boyadgiev, T. and Sayegh, A.H. 1992. Forms of evolution of gypsum in arid soils and soil parent materials. Pedologie, XL11-2, pp.171-182. 
[10] Okalebo, J.R., Gathua, K.W. and Woomer, P.L. (2002) Laboratory Methods for Soil and Plant Analysis: A Working Manual. TSBF, Nairobi.

[11] US Salinity Laboratory Staff (1954) Diagnosis and improvement of saline and alkali soils. US Department of Agriculture Handbook 60, Washington, DC.

[12] Fikret Ustaoğlu, Beyhan Taş, Yalçın Tepe and Halim Topaldemir, (2021) Comprehensive assessment of water quality and associated health risk by using physicochemical quality indices and multivariate analysis in Terme River, Turkey, Environmental Science and Pollution Research

[13] Elsiddig Eldaw, Tao Huang, Adam Khalifa Mohamed, Yahaya Mahama. (2021). Classification of groundwater suitability for irrigation purposes using a comprehensive approach based on the AHP and GIS techniques in North Kurdufan Province, Sudan, Applied Water Science 11:126 https://doi.org/10.1007/s13201-021-01443-z

[14]Mbagwu JSC. (1992). Improving the productivity of a degraded Ultisol in Nigera using organic and inorganic amendment. Part 2. Change in physical properties, Bioresource technology 42.

[15] Magesan GN. (2001). Change in soil physical properties after irrigation of two forested soils with municipal wastewater. New Zealand Journal of forestry science 31(2): 180;195.

[16] Mohammad, M.J. and Mazahreh, N. (2003) Changes in Soil Fertility Parameters in Response to Irrigation of Forage Crops with Secondary Treated Wastewater. Communications in Soil Science and Plant Analysis, 34, 1281-1294. http://dx.doi.org/10.1081/CSS-120020444

[17] Hazelton, P. and Murphy, B. (2007). Interpreting Soil Test Results: What do all the Numbers mean?. CSIRO Publishing, Collingwood, Victoria, 2007. xi+152 pp. Aus\$59.95, paperback. ISBN 978-0-643092-25-9.

[18] Kiran DH. Ladwani D, Krishna S, Vivek, D. Ramteke S. (2012). Impact Wastewater Irrigation on Soil Properties and Crop Yield. International Journal of Scientific and ResearchPublications, 2(10): 164 -172.

[19] Vieira C, Morais S, Ramos S, Delerue-Matos C and Oliveira, M.B.P.P. (2011). Mercury, cadmium, lead and arsenic levels in three pelagic fish species from the Atlantic Ocean: intra- and inter specific variability and human health risks for consumption. Journal of Food and Chemical Toxicology, 49: 923-932.

[20] Jomova K and Valko M. (2010). Advances in metal-induced oxidative stress and human disease. Journal of Toxicology, 283: 65-87.

[21] Berglund S, Davis RD and Hernite P. (1984). Utilization of sewage sludge on land: rates of application and long-term effects of metals. Dordrecht: D. Reidel Publishing, 216p.

[22] Rezapour S. and Samadi A. (2011). Nutr Cycl Agroecosys 269.

[23] Mohammad Rusan, M.J., S. Hinnawi, and L. Rousan. 2007. Long term effect of wastewater irrigation of forage crops on soil and plant quality parameters. Desalination 215:143-152. 
[24] Vassanda Coumar Mounissamy, Raghbendra Singh Parihar, Anil Kumar Dwivedi, Jayanta Kumar Saha, Selladurai Rajendiran, Brij Lal Lakaria \& Ashok Kumar Patra. (2021). Effects of Co-composting of Municipal Solid Waste and Pigeon Pea Biochar on Heavy Metal Mobility in Soil and Translocation to Leafy Vegetable Spinach. Bulletin of Environmental Contamination and Toxicology volume 106, pages 536-544 (2021)

[25] Rattan R.K., Datta S.P., Chhonkar P.K. Suribabu K. Singh A.K. (2005). Long-term impact of irrigation with sewage effluents on heavy metal content in soils, crops and groundwater-a case study. Agriculture, Ecosystems and Environment 109 (2005) 310-322

\section{Figures}

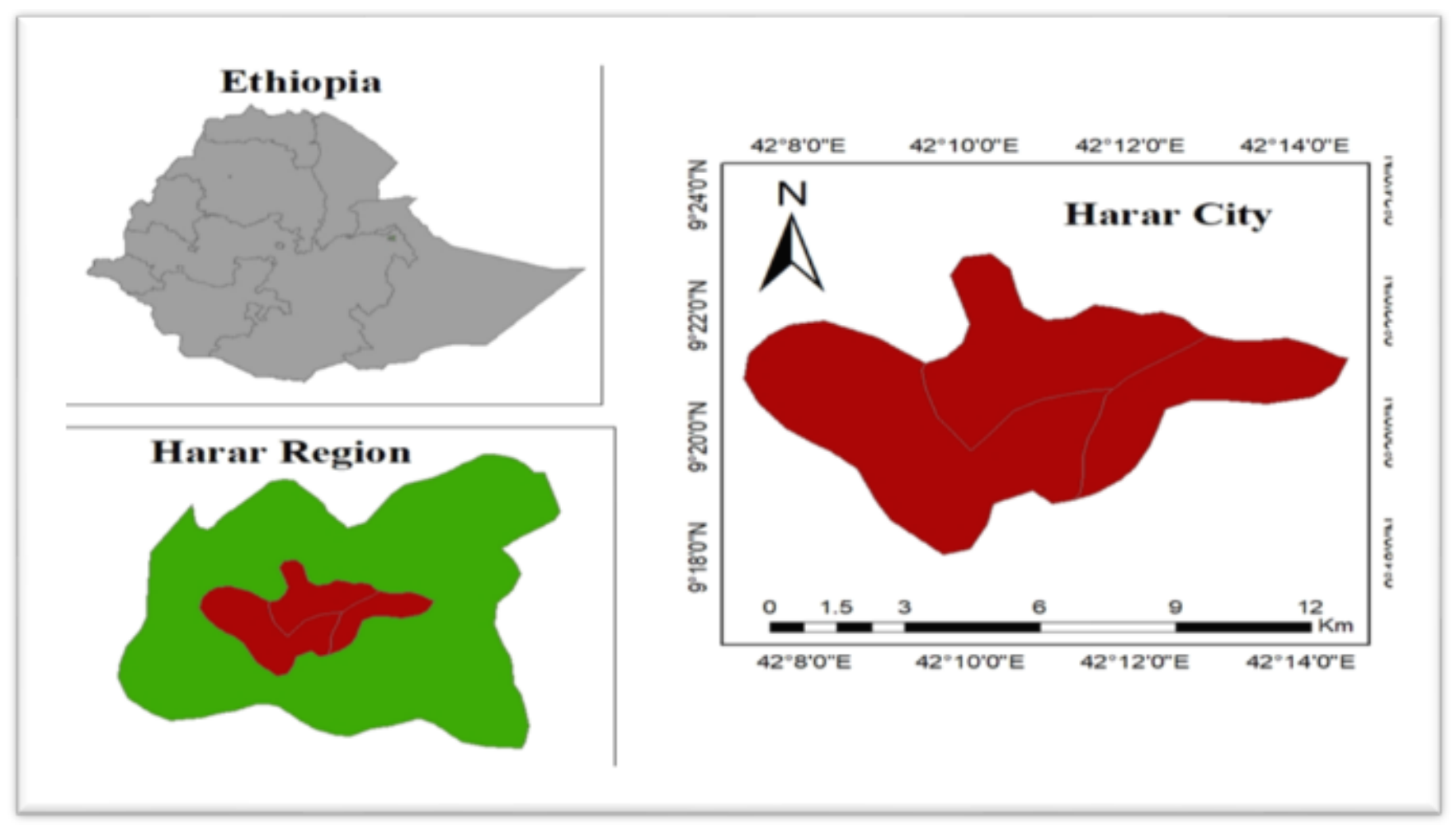

Figure.1.StudyArea Map

\section{Figure 1}

Map of study area 


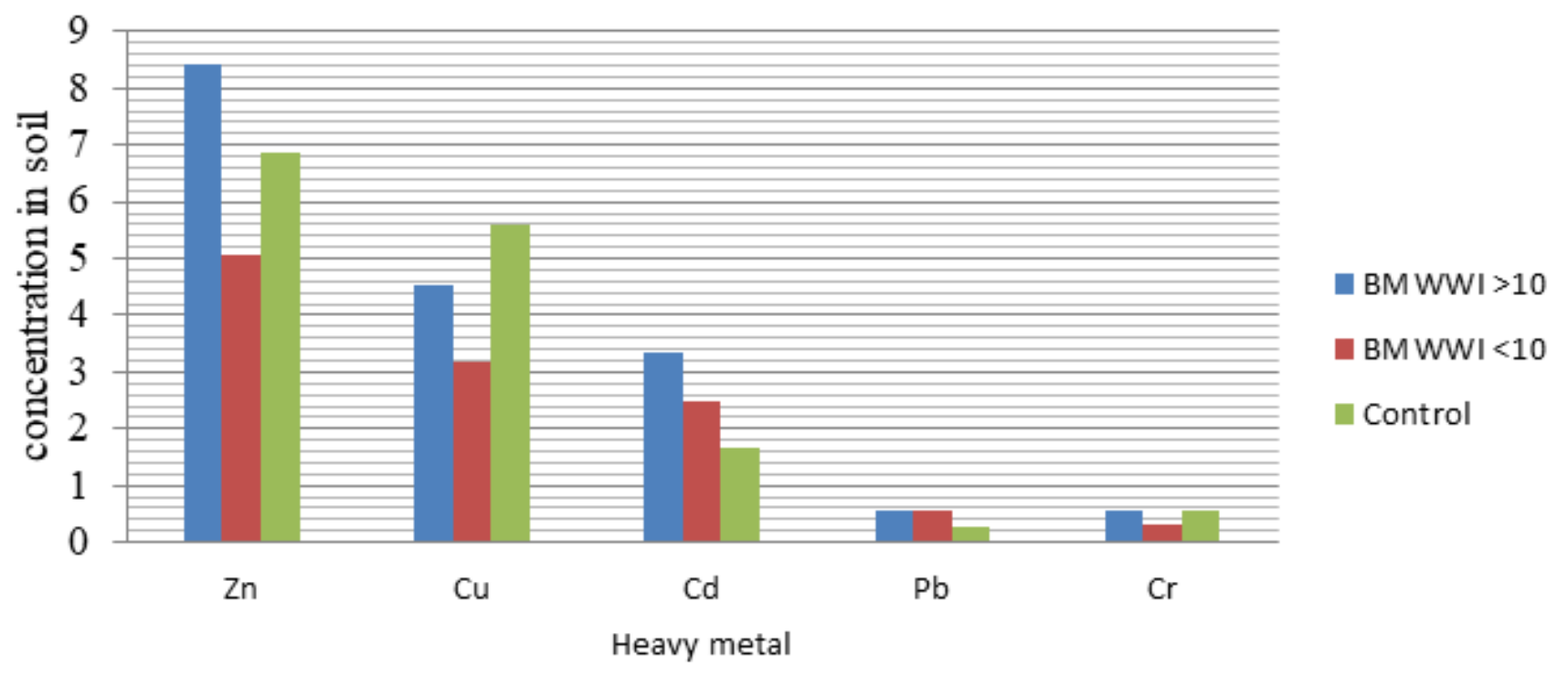

Figure 2

The concentration of heavy metal in the study sites.

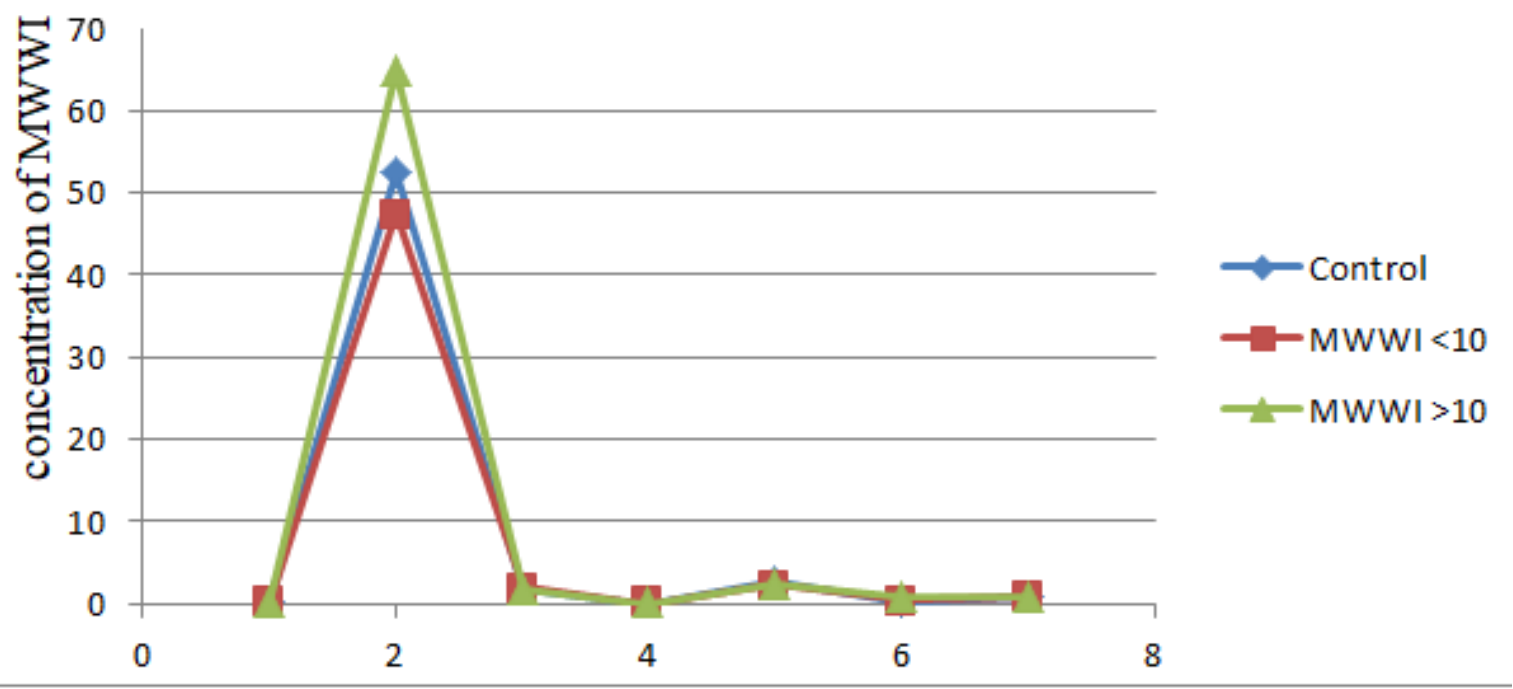

Figure 3

The concentration of different MWWI chemicals 